\title{
Postgraduate Students' Perceptions toward Student- Centered Learning (SCL): A Study of Afghan Postgraduate Students at TESL- University Technology Malaysia
}

\author{
Hamza Atifnigar, Wahidullah Alokozay, Zia ur Rahman Zaheer
}

\begin{abstract}
Afghanistan formal education has long been dominated by the traditional teaching method whereas students are likely to be passive. Therefore, this study aims to explore Afghan Post-graduate student's perception toward Student-Centered Learning (SCL) approach in terms of the perceived benefits, satisfaction, and the challenges they confronting in their studies. The study was conducted among 38 Afghan students from University Technology Malaysia (UTM). Questionnaire and a semi-structure interview tools have been used to collect data from students. The data was analyzed using descriptive statistics and thematic analysis. The findings of the study indicated that students are very satisfied from SCL approach, at the same time is beneficial for their field of studies but at the 1 they were facing with problems at the beginning of their studies but after a short while they were adapted with the system. It is recommended that future studies should expand to cover all the students who are studying in Malaysia Universities.
\end{abstract}

Keywords: Students-Centered learning, teacher- CenteredLearning, Challenges of SCL, attitudes of students, perception of students

\section{INTRODUCTION}

Experiences where students' learning is enhanced has become more crucial in the institutions of higher Educations from 1990 because of the decrease of the student's enrollment and diversification (Poon, 2013). According to Freire (2010), the process of teaching learning is also been changed as a result, result, parallel to the technological, socio-economic, and political aspects both in nature and quality. Teachers are been changed from instructors to facilitators, while students are changing from listeners to active participants.

There are two types of approaches in the area of education which are named as Student-Centered Learning (SCL) and Teachers Centered learning (TCL) approaches. Arco-Cobbah (2004) indicated that normally in universities mostly the teacher-centered learning (TCL) approach is practiced. Many scholars have claimed that Teachers Centered learning (TCL) which is considered as traditional method is not adequate to prepare the students to find jobs or to face the job challenges.

Revised Manuscript Received on March 13, 2020.

* Correspondence Author

Hamza Atifnigar*, Pursuing, Master's Degree in TESL, University Technology Malaysia. Email: Hamza.honaryar@gmail.com

Wahidullah Alokozay, Pursuing, Master's Degree in Education (TESL), University Technology Malaysia. Email: wahidullahalokozay123@gmail.com

Zia ur Rahman Zaheer, Senior Student of Master of Education (TESL), Technology Malaysia. zzia8927@gmail.com/zaheerzia888@yahoo.com

(c) The Authors. Published by Blue Eyes Intelligence Engineering and Sciences Publication (BEIESP). This is an open access article under the CC BY-NC-ND license (http://creativecommons.org/licenses/by-nc-nd/4.0/)
The Student-Centered Learning (SCL) which is considered to be teaching method that can help minimizing such problem and the two approaches have their own differences.

Bologna (1999) mentioned that Student-centered learning (SCL) is a learning approach, which was first started to be researched and analyzed long before the first Bologna Declaration of 19 June 1999 and was considered as one of the possible pedagogical approaches for higher education. MacHemer et al, 2007, \& Boyer, (1990) mentioned in their study that it can be understood from the term Student-centered learning, it is a method of learning or teaching that puts the learner at the center. While Studentcentered learning (SCL) is applied in higher education a shift is necessarily focused on from academic teaching staff to the learner. Many researches have shown that in Studentcentered learning (SCL) environment a lot of changes have been brought in the process of learning and teaching where not only learners' but also the teachers' experience are boosted (Freire, 2010; Tongsakul, Jitgarun \& Chaokumnerd, 2011; and Van Uden, Ritzen \& Pieters, 2013).

According to (Torres, 1998; Lizzio \& Wilson, 2005; Freire, 2010; and Lu, 2012), students and teachers are faced many challenges to bring up student-centered learning atmosphere. Numbers of changes given both to learners and teachers in Student-centered learning (SCL) environment, which are included recognition of students, collaborative and critical learning, and application of knowledge into real world problems and diversity of perceptions from students.

\section{LITERATURE REVIEW}

In 1905 Frank Herbert Hayward declared SCL for the first time in 1905 and then it was mentioned in John Dewey's writings in 1950s, it is worth mentioning that SCL is a concept which is considered to be traced back into the past of the beginning of the $20^{\text {th }}$ century (O'Sullivan, 2003; O'Neill \& McMahon, 2005). The relationship of the phrase SCL is connected to Carl Rogers and Jean Piaget's works and more lately with Malcolm Knowles' writings notion of self-directed learning in adult education (Burnard, 1999). According to Landau (2001), learners are to be active when they produce their learning mostly in higher level education and the scholars found out the through the prolepsis that In the constructivist learning theory the visionary position is principally constructed.

Published By:

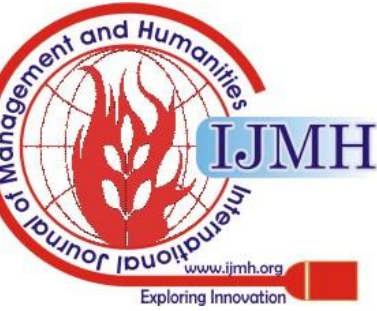


Mostly in educational literature the phrase SCL (Student-Centered Learning) is used. And according to (Burnard 1999; Taylor 2000), some other terms as varied educating, smart learning, learning based on experience and self-managed learning are used. Some other terms which are also use for SCL are; according to (Bonwell \& Eison, 1991) he defines it as active learning. (Bruffee, 1984), states that SCL is also known as collaborative learning. It can also be called Inquiry-based Learning. (Johnson, Johnson, \& Smith, 2006) know SCL as cooperative Learning. (Tien, Roth, \& Kampmeier, 2001) name SCL as peer led learning. (Michaelson, Knight, \& Fink, 2004), define SCL as teambased Learning. And according to (Mazur, 1997) it can be called peer instruction.

Student-Centered-Learning (SCL) and TeacherCentered-Learning (TCL) are the two kinds of teaching methods in the area of education. As Arco-Cobbah (2004), states in universities the teachers are normally use teachercentered methods and approaches. As these two approaches SCL and TCL have their own differences so many scholars claim that only the traditional methods are not enough for the learners to be prepared where they can get ideal fobs but another approach which is known as SCL and is based on learners learning is considered to be more helpful to overcome this problem.

According Means (1994), SCL method or approach is specially designed which facilitate learners some opportunities where they can have a smart participation in the learning process by changing the charge of managing, examining and creating an extent from the teacher to the student. Sablonniere, Taylor \& Sadykova, (2009), further mentioned that in SCL the job of the teacher is more like a facilitator than providing knowledge to the learners. Candella et al., (2006) and Immordino-Yang \& Damasio, (2007) added "The one-way transferring knowledge which was used before in many fields for the past generations are not considered enough and adequate to prepare the learners and make them able to face the challenges in today society, because in today's modern and technological world learners do not have only have to get knowledge. According to Meece (2003), we could be able to gain this to change the focus from transferring knowledge to educating where we can provide opportunities so the learners will not be only passive but they will actively participate in the process of knowledge.

Furthermore, Diekelman, Ironside and Tanner (2004) added that the teacher does not have to present knowledge actively but he/she may be as a guide to create and monitor good opportunities and provide contexts where only the learners are responsible to gain their aims and goals by themselves which are set by them as groups. A contentheavy syllabus is needed to be shifted students centered syllabus since little room for the improving is left for necessary skills for instance, a good order for students' thinking, the skills how to make some decisions, some other skills helpful to find the solutions for problems and how to assist self and peer or other group member.

According to Hill and Land (1997), this could be achieved in a better way by the learners centered pedagogy at every level of education as well as in higher education. SCL approaches provide learners opportunities where they can examine more complex problems where they use a wide range of resources and they are being able to improve their ways and methods for finding the obstacles and find easily applied adjustments to the obstacles in a more combined way.

As Tseng, Chiang and Hsu (2008) stated that there is needed much more time for learners to acquire and adopt new methods and ways when they are using SCL for the first time as a teamwork and learn how to overcome the problems they face. According to Carlisle \& Ibbotson (2005), as learners change their style of learning from TCL to SCL approach it therefore could be a challenging environment. According to Arco-Cobbah (2004), the higher educational institutes normally practice in their teaching the TCL. But it is seen that only traditional methods are not considered adequate enough where learner could be prepared for finding jobs as well as those challenges they face in their jobs. One more approach which is known as SCL on is centered on the students and is seen to be used by teachers in higher educational institutes and is considered to be adequate that can help to overcome this problem.

Sadykova (2009) says that both approaches have differences of their own and adds that the TCL method has the characteristics of predominant use of some traditional approaches used in the process of teaching and here the instructor facilitate some structured data and uses in the lectures while learners only listen and write important points (Sablonniere, Taylor \& Sadykova, 2009). (Means, 1994), stated that the student-centered learning is developed to which makes the learners to have a smart participation through the process of learning where the jobs of managing, creating some contents and assessing are shifted from the instructors to the students. Furthermore, (Sablonniere,Taylor \& Sadykova, 2009), stated that here the role of a teacher is like facilitator in the process of learning rather than he/she provides the knowledge.

Khairum, Salim and Ashadi (2013), added that if we want the SCL as an efficient so the perception of learners for acquiring knowledge mostly in universities and colleges are to be changed. Here in SCL methods the instructor only acts as a facilitator inside the class and only assists the learners and provide the information and only the learners are to be engaged in the process of learning and teaching. The learners are responsible for the process of learning. Researchers found out that the particular survey of the learners that they agree and mention that to the syllabus and the background of the learners only providing lectures are the suitable teaching method.

According to $\mathrm{Yu}$ (2012), in Gao-Kao examination which is considered where students' future life is influenced because the in Chinese schools the competition in situation is fierce specially. Because as the learners get high scores, they get the better chances in different circumstances, for instance, in schools and in choosing colleges and universities. In developed countries and regions, the lectures are common.

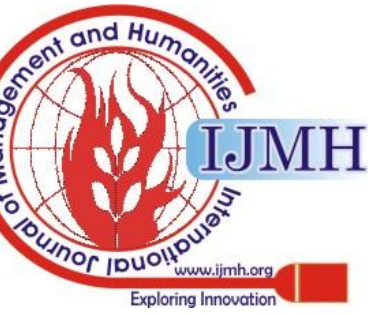


Furthermore, Freire, 2010; and Zabit, 2010), mentioned that if the students act like that specially in class listening to lectures. As the learners move and take participation in the class activities effect their participation and most of the times conclude in provision of learners from taking part in the class activities and predominance by few in the class. Most of the teachers think that if their role is being as a facilitator they will lost their power and influence over the class and the students and (Bhutto, 2011), stated that for instructors it will be complicated to know as they change their role as facilitator, this may be due to the influence of culture lacking skills of teaching and learning process or they may not expert in making the learners engaged and it is connected to the knowledge of the instructors and if the instructors leave the process of learning and teaching only to learners they think it can minimize the power and control they have over the class and the class environment.

According to Lizzio \& Wilson (2005), the views of learners on appreciating and obeying instructors limited learners in listening to the lessons of their instructors quietly. Students not only expose their frequency of respect to their instructors, but also, they sit passively in the classroom which lead them toward fear; fear could be seen as impoliteness or imprudence. However, such fears of mistakes and seems foolishness by students develops to withholding their thoughts for participation in the classroom discussion and interaction.

In addition, Torres (1998) asserted that the diversity of views from learners has been a significant challenge for SCL. Recently, there have been many areas in the world where people maintain various perceptions. Consequently, both instructors and learners may have absolutely varied and sensitive positions on matters such as, religion, unisex marriage, believes, etc... which sometimes create confusion and misunderstanding among learners and between learners and teachers. Button, (2011) indicated that in learner-centric learning approach, a pedagogy based on participatory approach toward teaching is more effective than traditional teaching. At the same time Tran \& Lewis, (2012) stated that "Different methods focused on two-way of communication can be used with regard to related topics or subject matters. Finding the most appropriate pedagogical approach promotes not only students' comprehension, and acquisition of competencies, but also facilitates their participation, communication skills, independent thinking, and teamwork".

\section{METHODOLOGY}

The study is based on mixed research method where both qualitative and quantitative data is collected to study students' perceptions toward SCL in Afghanistan. Population of the study consists of thirty-eight TESL (Master's Program) Afghan students currently studying at Education Faculty, University Technology Malaysia (UTM), and Malaysia. The population comprises of four female and thirty-four male students aging between 25 to 35 years. All of the participants are holding assistant lecturer position at different universities from Afghanistan. Primary data for the study were collected through questionnaire and interview. The quantitative data was collected through close-ended questionnaire adopted from a previous study by Hamza (2013) \& Rissaphop Treesuwan (2016). The questionnaire consisted of three constructs namely; demographic, perception and challenges.

The questions in the questionnaire are focused more on the students' perceptions and attitudes towards the implementation of Student-Centered Learning approach and on the challenges faced by the students who have TeacherCentered Learning background both inside and outside the classroom. Students were asked to answer all the questions in the questionnaires. The questionnaire was distributed through Google Form to all thirty-eight students. Among these questionnaires, all the 38 questionnaires were collected successfully. The qualitative data was collected through semi-structured interview with seven students to collect in-depth information about the challenges they face while applying SCL in the classroom and the challenges they face.

\section{FINDING AND DISCUSSION}

After analyzing the data from both questionnaire and interview we came up with a result that student-centered learning (SCL) approach is important to Afghan Postgraduate students (AFGs) in their field of studies see figure 1.

AFPG Students' perception toward Importance of SCL approach to their field of studies

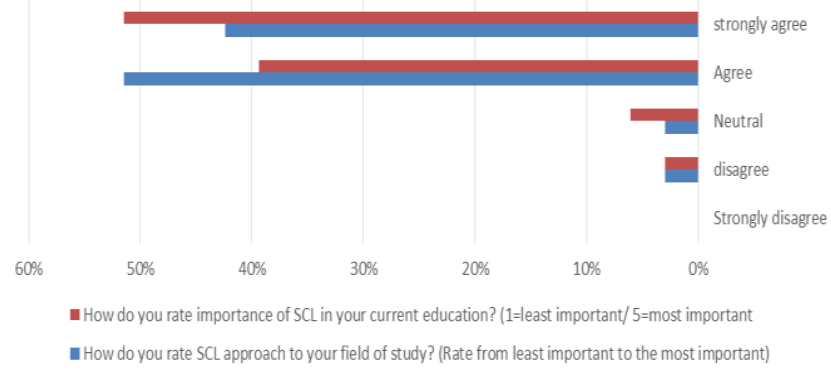

Figure 1

They are very keen to be under the umbrella of SCL while they have background in Teacher-centered learning (TCL). However, this research is used to gain perceptions of postgraduate students and challenges of them toward Student-centered learning (SCL) approach.

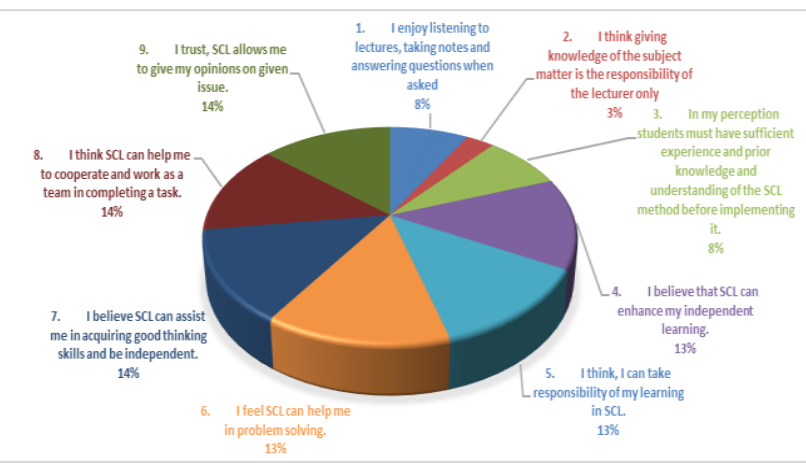

Figure 2
Published By: \& Sciences Publication
Blue Eyes Intelligence Engineering 
As it can be seen in figure 2 about the student's perception toward SCL approach. That the statement which have been given in the form of agreement/disagreement to the respondents to know their perceptions about SCL approach. From all 33 respondents, 100\% of them responded both in questionnaire and interview that SCL can enhance their independent learning. Besides, 93.9\% of the participants also agreed that through SCL techniques they can take responsibilities of their own learning, while $6.1 \%$ disagreed with this statement. Furthermore, $59.4 \%$ of the respondents agreed that they enjoy listening to lectures, taking notes and answering questions when they are asked and $40.6 \%$ of respondents disagreed with this statement. However, from the finding of Khairum, Fazilah and Ashadi (2013) indicated that $88 \%$ of the responded agreed with this statement.

On the other hand, all of the participants agreed that SCL approach assisted them in problem solving. At same time Rissaphop and Tanes (2016) showed in their research that most of the students agreed that SCL enhanced their problem solving. As, AFPG students teaching background are from Teacher-Centered Learning TCL approach and most of the them mentioned in their interviews that before SCL involvement they were facing lots of problems, but hopefully now we are capable in problem solving in our field of studies. In addition, $100 \%$ of the respondents showed their agreements in connection to the SCL, it was indicated both from the result of questionnaire and interview that SCL further helped them in acquiring good thinking skill and felt more autonomous when they are doing self or in group learning.

Additionally, most of AFPG think that SCL help them to cooperate and work as a team in completing any given task and most of them believe that team working led them to be so-called supervisor, leader and developer of the team's activities. They further signaled that if any team member fails in doing the given task or project then their result of marks go to every individual of the group, that's why students need to cooperate with each other in completing the assignment given by the lecturer, The agreement level of all participants indicated in which they believe, SCL allows us to give our opinions on given issue. As matters of fact, information that resulted from the interview, some of them denoted that they are more confident in presenting their opinions about issue assigned by the lectures both individually or in group inside of classroom or outside of the classroom.

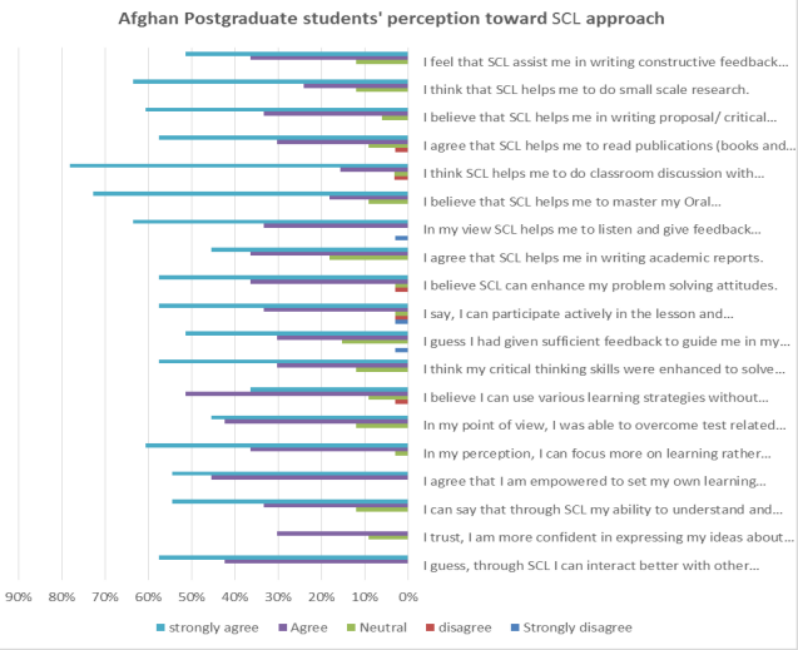

Figure 3

Retrieval Number: G0723034720/2020@BEIESP
However, the data reveal from figure 3 about general perception of students in relation to the SCL approach. SCL help them to master their oral presentations in the classroom. In fact, presentation provided them the opportunities to overcome anxieties of speaking that they had before joining SCL approach at UTM. Besides, most of the students declared in the interview that after joining SCL approach and performed numbers of assignment given by the lecturers, they further said that they can write proposal, journal article, review paper, conduct small scale research and doing critical review for their assignments which are in fact a great outcome of the SCL approach. Most of the students who were asked regarding confidence, they said that it was SCL that mastered our confidence at any activities which were relating the techniques of SCL.

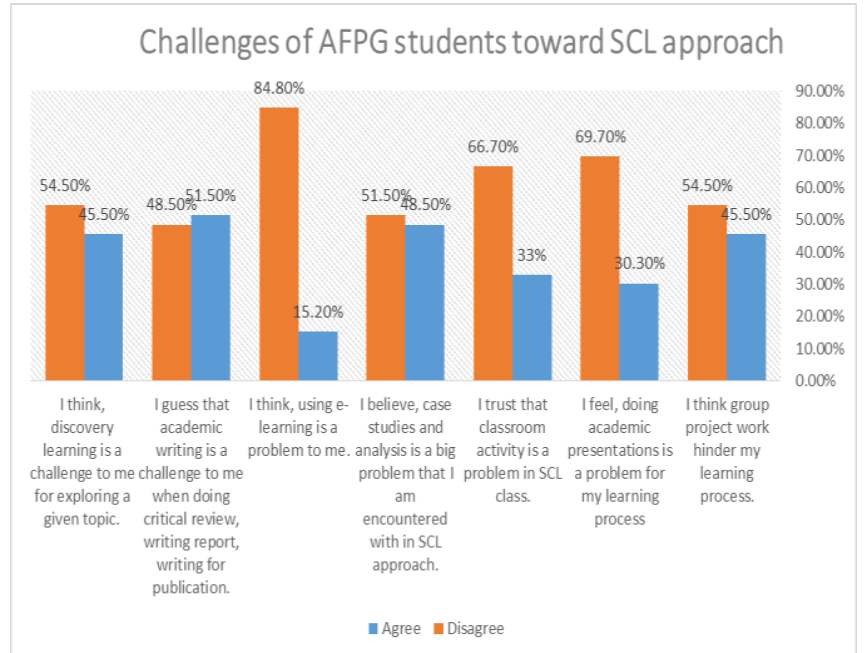

Figure 4

The data obtained from figure 4 and semi-structure interview about the challenges AFPG are facing when under SCL approach. It is resulted from the interview studying with SCL approach was problematic at the beginning of the semester but after working hard and adapting with environment then they overcome those challenges. Most of the students taught that they had problems in keeping classroom discussion with their peers and lecturers. On the other hand, some of the interviewees expressed their concern that they could not understand overall aspects of a group projects because of unavailability of the students for discussion of the projects. For example, if they conduct a small-scale research, they had to divide each segments of the project into piece and dived each to the students to do. At final, they were not able to know all parts of the project, therefore group work was a challenge toward their educational achievement. Finally, 51.5\% of respondent's believed that academic writing is a challengeable skill to us when we are writing for publication, critical writing and writing reports.

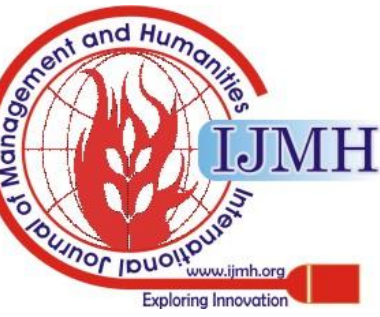




\section{LIMITATION:}

The SCL approach, however, is designed to provide students with opportunities to take a more active role in their learning by shifting the responsibilities of organizing, analyzing and synthesizing content from the lecturer to learner (Means, 1994). The limitation of this research paper is that only the Afghan Postgraduate TESL students who have Teacher Centered Learning Background but it would be better to cover all the students from different faculties because most learners who are studying at UTM and other universities in Malaysia have Teacher Centered Learning background and it is very important to know and understand their perception being in a new teaching approach to overcome the obstacles in their future learning. Mostly, those students who come from back warded countries have a Teaching Centered Learning approach background.

\section{CONCLUSION}

This research was aimed to find out AfghanPostgraduate Students; perception toward Student-Centered Learning approach mainly their satisfaction, advantages and the challenges they face when studying at TESL-UTM. The gathered data both from questionnaire and semi-structure interview indicate that all student preferred SCL approach because it help them in improving their problem solving, critical thinking, and creativity skills and headed them to be autonomous and confident learners. At the meantime, They declared that the lessons, reading journal article, working in e-learning, doing classroom activities and presentation were problematic at the beginning of their studies but after completing one semester they overcome those obstacles.

\section{REFERENCES}

1. Arko-Cobbah A. (2004) 'The Role of Libraries in StudentCentered Learning: The Case of Students from the Disadvantaged Communities in South Africa'. The International Information and Library Review,36(3),263-271.

2. Bologna Declaration (1999). The Bologna Declaration of 19 June 1999. Retrieved, August 20, 2016 from http://www.magna-char ta.org/resources/files/BOLOGNA_DECLARATION.pdf

3. BOYER, E. (1990) Scholarship Reconsidered: Priorities of the Professoriate. New York:The Carnegie Foundation for the Advancement of Teaching.

4. Brown, R. (2008). Blending learning: Rich experiences from a rich picture. Training and Development in Australia, 30 (3), 14-17.

5. Bruffee, K. A. (1984). Collaborative Learning and the "Conversation of Mankind". College English, 46, 635-652

6. Burnard, P. (1999). Carl Rogers and postmodernism: Challenged in nursing and health sciences. Nursing and Health Sciences, 1, pp.241-247.

7. Candella L, Dalley K \& Benzel-Lindley J. (2006). A case for learning-centered curricula. Journal of Nursing education. 66-59

8. Carlile O \& Jordan A. (2005). It works in practice but will it work in theory? The theoretical underpinnings of pedagogy, In S

9. Chang, Shu, Liang, Tseng, \&Hsu (2014). Is blended e-learning better than traditional Classroom learning for vocational high school students? 15(2), 142-146.

10. Crouch and Mazur. (2001). Peer instruction: Ten years of experience and results. American Association of Physics Teachers .

11. Diekelman N. (2002). "Too much content...." Epistemologies' grasp and nursing education. Journal of Nursing Education.

12. Freire, P. (1992). Pedagogy of hope: Reliving pedagogy of the oppressed. London: Continuum

13. Freire, Paulo. (2010). Pedagogy of the Oppressed. New York: The Continuum International Publishing Group Inc
14. Hill, J., \& Hannafin, M. J. (1997). Cognitive strategies and learning from the World-Wide Web. Educational Technology Research and Development, 45(4), 37-64

15. Khairum bin Hamzah1, F. S. (2013). Students' Perceptions and Attitudes towards Student-Centered Learning: A Study of Manufacturing Engineering Technology Students in Universiti Teknikal Malaysia Melaka. Journal of Human Capital Development, 59-56.

16. Landau, M. J., Vess, M., Arndt, J., Rothschild, Z. K., Sullivan, D., \& Atchley, R. A. (in press). Embodied metaphor and the "true" self: Priming entity expansion and protection influences intrinsic self-expressions in self-perceptions and interpersonal behavior. Journal of Experimental Social Psychology

17. Machemer, P. L., \& Crawford, P. (2007). Student Perceptions of Active Learning in a Large Cross-Disciplinary Classroom. Active Learning in Higher Education, 8(1), 9-30. http://dx.doi.org/10.1177/1469787407074008

18. Meece JL. ( 2003). 'Applying Learner-centered Principles to Middle School Education'. Theory into Practice, 42(2):109-116.

19. Michaelsen, L. K., Knight, A. B., Fink, L.D. (2004) Team-Based Learning: A Transformative Use of Small Groups in College Teaching. Stylus, Sterling, VA

20. Moore, G O'Neil \& B McMullin (eds). Emerging Issues in the Practice of University Learning and Teaching. Dublin: All Ireland Society for Higher Education (AISHE.(

21. Poon, J. (2013), Blended learning: an institutional approach for enhancing students' learning experiences, Journal of online learning and teaching, vol. 9, no. 2, pp. 271-288

22. Sablonnie, Talor and Sadykoa. (2009). Challenges of applying student-centered approach to learning in the context of education in Kyrgyszstan. International Journal of Educational Development, 628-634.

23. Taylor, P. G. (2000). Changing expectations: Preparing students for flexible learning. The International Journal of Academic Development, 5(2), pp. 107-115.

24. Tien, Roth, \& Kampmeier, (2001). Implementation of a Peer-Led Team Learning Instructional Approach in an Undergraduate Organic Chemistry Course. Journal of Research in Science Teaching. PP. 606-632 .

25. Treesuwan and Tanitteerapa. (2016). Students Perception on Learner-centered Teaching Approach: The New Educational Review, 151-156

\section{AUTHORS PROFILE}

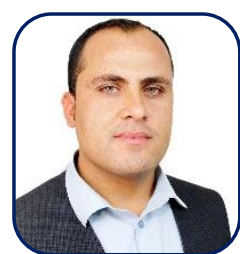

Hamza Atifnigar, is a senior lecturer at Laghman University. He has been an EFL teacher in different parts of Afghanistan for the last fifteen years. Currently, he is pursuing his Master's Degree in TESL at University Technology Malaysia. Email: Hamza.honaryar@gmail.com

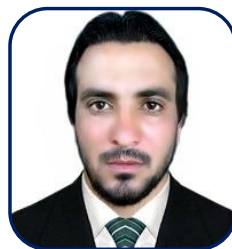

Wahidullah Alokozay, is a senior experienced EFL Lecturer at Paktia University of Afghanistan. He is currently doing his Master's Degree in Education (TESL) at University Technology Malaysia. Email: wahidullahalokozay123@gmail.com

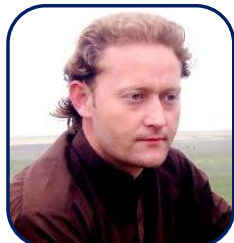

Zia ur Rahman Zaheer, is a qualified senior EFL lecturer at Baghlan University, Faculty of Literature and Humanities. His is a senior student of Master of Education (TESL) at Technology Malaysia. Email zzia8927@gmail.com/zaheerzia888@yahoo.com

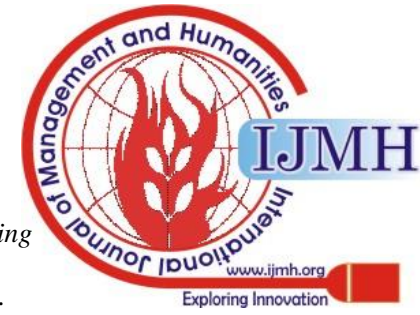

